6

\title{
Efficacy of bladder training in adults with overactive bladder: A systematic review protocol
}

Anna Karoline Lopes. Rocha ${ }^{1 \neq}$, Silvia Elizate Monteiro ${ }^{2,3 \neq}$, Maria P. Volpato ${ }^{1,2}$, Dinah Verleun de Paula e Silva ${ }^{4}$, Lilian Valim ${ }^{3}$, Cássio Riccetto ${ }^{2 \ddagger}$, Simone Botelho ${ }^{1,27^{*}}$

${ }^{1}$ Postgraduate Program in Rehabilitation Sciences, Motor Science Institute of the Federal University of Alfenas (UNIFAL-MG), Alfenas, Minas Gerais, Brazil

${ }^{2}$ Postgraduate Program in Surgical Science, School of Medical Sciences of the State University of Campinas (UNICAMP), Campinas, São Paulo, Brazil

${ }^{3}$ Physiotherapy Department Pontifical Catholic University of Minas Gerais (PUC-MINAS), Belo Horizonte, Minas Gerais, Brazil

${ }^{4}$ Post-graduation Program Latu Sensu in Women's Health Physiotherapy and Pelvic Dysfunctions Faculdade de Ciencias Medicas de Minas Gerais (FCMMG), Belo Horizonte, Minas Gerais, Brazil

6 These authors contributed equally to this work.

${ }_{\ddagger} \mathrm{AKLR}$ and SEM are first authors on this work. CR and SB are last authors on this work.

\section{${ }^{*}$ Correspondent author}

E-mail: simone.botelho@unifal-mg.edu.br (SB) 
medRxiv preprint doi: https://doi.org/10.1101/2022.03.01.22271687; this version posted March 2, 2022. The copyright holder for this preprint (which was not certified by peer review) is the author/funder, who has granted medRxiv a license to display the preprint in perpetuity.

It is made available under a CC-BY 4.0 International license .

\section{Efficacy of bladder training in adults with overactive bladder: A systematic} review protocol

\section{Metadata}

\section{Funding Statement}

This study is supported by the Coordenação de Aperfeiçoamento de Pessoal de Nível Superior - Brazil (CAPES) through the Graduate Program in Rehabilitation Sciences, UroPhysiotherapy Laboratory of the Postgraduate Program in Rehabilitation Sciences - Federal University of Alfenas, UNIFAL-MG, Brazil and the Postgraduate Program in Surgical Science, School of Medical Sciences of the State University of Campinas (UNICAMP), Campinas, São Paulo, Brazil, as well as the Fundação de Amparo à Pesquisa do Estado de Minas Gerais - FAPEMIG and Research Incentive Fund, PUC MINAS, MG, Brazil, for the design, implementation, interpretation, and publication of the study. The funders had not and will not have a role in study design, data collection and analysis, decision to publish, or preparation of the manuscript.

\section{Competing interests}

All authors don't have conflicts of interest with the present study.

Data availability

43 All relevant data from this study will be made available upon study completion. 


\section{Abstract}

\section{Introduction}

The aim of this systematic review will be to investigate and update whether bladder training can promote improvement of symptoms of overactive bladder syndrome with or without urgency urinary incontinence in adults.

\section{Methods}

We will perform a systematic review according to the Cochrane methodology of randomized controlled trials. An overall search strategy will be developed and adapted for each database. A bibliographic search will be conducted in eight databases PubMed, PEDro, SciELO, LILACS, Cochrane Library, Web of Science, EMBASE, CINAHL, by manual searching. The MeSH terms will be "Bladder Training", "Bladder Drill”, "Bladder Re-education”, "Bladder Retraining", "Bladder Discipline”, "Overactive Bladder", "Bladder, Overactive”, “Overactive Urinary Bladder", “Urinary Bladder", "Overactive, Urinary Bladder", "Bladder, Urinary”, "Urinary Bladder Disease”, "Bladder Disease", "Bladder Detrusor Muscle" and "Detrusor Muscle, Bladder". Meta-analysis, if plausible, will be performed by the software Review Manager 5.4. Primary outcomes: symptoms of overactive bladder syndrome (urinary urgency with daytime voiding frequency, nocturia with or without urgency urinary incontinence), and cure/improvement assessed by instruments. Secondary outcomes: quality of life, functional assessment, validated scale/questionnaire and adverse events. Quality assessment will be performed by Cochrane instrument and quality of evidence will be assessed by GRADE.

\section{Discussion}

This study is a review of randomized controlled studies to analyze the efficacy of bladder training in improving the symptoms of adults with overactive bladder syndrome. The study design of randomized controlled trials for a higher level of scientific evidence was chosen. The aim is to obtain results that allow further studies and evidence that this intervention generates beneficial effects in the sample studied. 
medRxiv preprint doi: https://doi.org/10.1101/2022.03.01.22271687; this version posted March 2, 2022. The copyright holder for this preprint (which was not certified by peer review) is the author/funder, who has granted medRxiv a license to display the preprint in perpetuity. It is made available under a CC-BY 4.0 International license .

\section{Trial registration}

76 Systematic review registration: PROSPERO CRD42022301522.

77 Keywords: Behavior Therapy; Exercise Therapy; Rehabilitation; Urinary Bladder,

78 Overactive; Urinary; Incontinence; Conservative Treatment. 
medRxiv preprint doi: https://doi.org/10.1101/2022.03.01.22271687; this version posted March 2, 2022. The copyright holder for this preprint (which was not certified by peer review) is the author/funder, who has granted medRxiv a license to display the preprint in perpetuity.

It is made available under a CC-BY 4.0 International license.

\section{Introduction}

According to the International Continence Society (ICS), the overactive bladder (OAB) is a multifactorial clinical syndrome associated with intrinsic and extrinsic factors, and is defined as the presence of symptoms of urinary urgency, daytime voiding frequency and/or nocturia, with urinary incontinence (OAB-wet) or without (OAB-dry), in the absence of urinary tract infection or other detectable disease [1-6]. The OAB tends to directly impact the quality of life of individuals, affecting self-esteem and interpersonal relationships, and contributing to social isolation [7,8]. However, the search for treatment is usually delayed due to embarrassment and lack of knowledge [9].

Its prevalence is quite variable (2 to $53 \%$ ), ranging from 2 to $35 \%$ among men and 3 to $41 \%$ among women, tending to increase with age in both genders $[8,10,11,12]$. The higher prevalence of the female population may be related to different factors, which was suggested by Peyronnet et al. (2019), which highlights the relevance of phenotypes for a better understanding of the trigger mechanisms and the importance of the individualized approach [13].

On the other hand, $O A B$ is a dynamic condition, with a remission rate of $49 \%$ in OAB-dry and $26 \%$ in OAB-wet women, which tends to be costly for public health.

According to international guidelines, low-cost and low-complexity therapeutic strategies are recommended as first-line treatment, aiming to promote a good costbenefit relationship as well as quality of life in individuals with $O A B$ [3,5,7,8,14-18].

The first-line conservative approach to the symptoms of OAB-wet or OAB-dry includes behavioral interventions, which consists of strategies that modify lifestyle, life habits, and patient environment, with scheduled voiding regimens, including bladder training (BT) and pelvic floor muscle training (PFMT) [16-19]. BT has been shown to be important, not only for the results presented, but because it has low cost, low complexity and reduced side effects [20].

BT consists of a set of techniques that help individuals to delay voiding through activities that require mental concentration, such as relaxation or distraction techniques, often associated with repeated contractions of pelvic floor muscles (PFM), which provide an inhibitory reflex of the detrusor (Urethrosphincteric guarding reflex) $[18,21,22]$. Therefore, while the individual to delay voiding, the voluntary contractions of PFM activate afferent stimulus, via the pudendal nerve to the sacral center of the urination with inhibitory responses to the detrusor through the pelvic nerve 
medRxiv preprint doi: https://doi.org/10.1101/2022.03.01.22271687; this version posted March 2, 2022. The copyright holder for this preprint (which was not certified by peer review) is the author/funder, who has granted medRxiv a license to display the preprint in perpetuity.

It is made available under a CC-BY 4.0 International license .

112 (Perineodetrusor inhibitory reflex), resulting in increased intervals between the 113 voidings [22].

114 The review published was study observed that are limited evidence available, 115 what suggests that BT may be helpful for the treatment of individuals with symptoms 116 of $\mathrm{OAB}$, but there was also not enough evidence to determine whether BT was useful 117 as a supplement to another therapy, either by the quality of evidence of the studies or 118 by the sample size, confidence interval or estimates of effect [23].

119 Considering this context, the aim of this study is to investigate the effect of BT 120 on the symptoms of OAB-wet or OAB-dry in adults, through a systematic review of 121 available randomized clinical trials (RCTs).

\section{Systematic review}

\section{Study inclusion and exclusion criteria}

Inclusion Criteria

126 RCTs of adults over 18 years old with OAB, with or without urgency urinary 127 incontinence, receiving any kind of BT intervention with or without supervision, to 128 prevent and/or reduce the symptoms of OAB.

Exclusion criteria

130 Case studies, cross-over studies, gray literature studies, or those that do not have the 131 separation of the groups nor details of the adequate protocol.

\section{Outcomes}

Primary outcomes

134 Cure/improvement of the $\mathrm{OAB}$ symptoms (urinary urgency with daytime voiding 135 frequency, nocturia with or without urgency urinary incontinence) assessed by quantity 136 instruments. 
medRxiv preprint doi: https://doi.org/10.1101/2022.03.01.22271687; this version posted March 2, 2022. The copyright holder for this preprint (which was not certified by peer review) is the author/funder, who has granted medRxiv a license to display the preprint in perpetuity.

It is made available under a CC-BY 4.0 International license .

Quality of life, functional assessment and adverse events.

\section{Literature search strategies}

140 A way strategy will be created and adapted for searching the databases PubMed,

141 Physiotherapy Evidence Database (PEDro), Scientific Electronic Library Online 142 (SciELO), Latin American and Caribbean Literature in Health Sciences (LILACS), 143 Central Cochrane Library, Web of Science, EMBASE, CINAHL (Cummulative Index to 144 Nursing and Allied Health Literature), and by manual searching to identify studies 145 involving the above-mentioned interventions. Last date of search will until December 146 2022. There will be no language restrictions. MeSH terms that will be used for our 147 searches are "Bladder Training”, "Bladder Drill”, "Bladder Re-education”, "Bladder 148 Retraining", "Bladder Discipline", "Overactive Bladder", "Bladder, Overactive", 149 "Overactive Urinary Bladder", “Urinary Bladder", "Overactive, Urinary Bladder", 150 "Bladder, Urinary", "Urinary Bladder Disease", "Bladder Disease”, "Bladder Detrusor Muscle" and "Detrusor Muscle, Bladder".

\section{Data collection and analysis}

At this study, for each search strategy, two reviewers will independently evaluate the studies gathered from the databases in the order: title, abstract and full reading. All studies potentially eligible for inclusion in the review will be selected for full reading. In case of disagreement, a third reviewer will be consulted.

\section{Data extraction and management}

Data extraction for eligible studies will be performed by two reviewers (AKLR e DPVS) who will independently extract data from articles that meet the inclusion criteria. A standardized form will be used to extract the following information: study characteristics (design, randomization method, blinding, allocation generation and concealment, statistics); participants; interventions; clinical outcomes (types of outcomes measured: dichotomous or continuous as shown in Table 1. 
medRxiv preprint doi: https://doi.org/10.1101/2022.03.01.22271687; this version posted March 2, 2022. The copyright holder for this preprint (which was not certified by peer review) is the author/funder, who has granted medRxiv a license to display the preprint in perpetuity.

It is made available under a CC-BY 4.0 International license .

Table 1. Characteristics of the Studies

166

167

168

169

170

171

172

173

174

175

176

177

178

179

180

181

182

183

184

185

186

187

\begin{tabular}{|c|c|c|c|c|c|c|c|}
\hline $\begin{array}{c}\text { Title / } \\
\text { Author/ } \\
\text { year } \\
\text { (country) }\end{array}$ & $\begin{array}{c}\text { Number of } \\
\text { participants } \\
\text { per group }\end{array}$ & $\begin{array}{c}\text { Outcome } \\
\text { measure and } \\
\text { OAB } \\
\text { Symptoms }\end{array}$ & $\begin{array}{c}\text { Primary } \\
\text { Outcomes }\end{array}$ & $\begin{array}{c}\text { Interventions in } \\
\text { each group } \\
\text { (protocols) }\end{array}$ & $\begin{array}{c}\text { Follow-up } \\
\text { (Simplified) }\end{array}$ & Results & $\begin{array}{c}\text { Grade } \\
\text { Score }\end{array}$ \\
\hline & & & & & & & \\
\hline & & & & & & & \\
\hline
\end{tabular}

Study characteristics related to the configuration; the number of participants according to the group; intervention in each group, outcomes measures; and follow up, results and grade score.

OAB: Overactive bladder

Studies that do not meet the exclusion criteria will be excluded and added in Table 2 with reason.

Table 2. Exclusion criteria from systematic review and meta-analysis of randomized controlled trials

\begin{tabular}{|l|l|l|}
\hline First Author, Year of publication & Title & Reasons for exclusion \\
\hline & & \\
\hline & & \\
\hline
\end{tabular}

Exclusion Table for the systematic review and meta-analysis of randomized controlled trials to evaluated the effects of $B T$ in individuals with $\mathrm{OAB}$-wet or $\mathrm{OAB}$-dry

\section{Methodological quality, risk of bias and statistical report}

At this study will be measure the methodological quality the risk of bias of Cochrane Handbook of Interventions Systematic Reviews will be used, which assesses the following domains: allocation generation; concealment of allocation; blinding (of participants and researchers) and blinding of outcome assessment; the presence of incomplete data; reporting bias of information and other types of bias. The results to these domains may be "High", "Low" or "Uncertain". The final grade of the study will 
medRxiv preprint doi: https://doi.org/10.1101/2022.03.01.22271687; this version posted March 2, 2022. The copyright holder for this preprint (which was not certified by peer review) is the author/funder, who has granted medRxiv a license to display the preprint in perpetuity.

It is made available under a CC-BY 4.0 International license .

be based on the responses given to the first three domains and will be classified as having high, low or uncertain risk of bias. We will provide summaries of intervention effects for each study, calculating ratios (for dichotomous outcomes) or standardized mean differences (for continuous outcomes). Therefore, if possible, due to the range of different outcomes measured across the small number of existing trials, we will conduct a meta-analysis. However, if it is possible to have a study with the same type of intervention, a comparator, and the same outcome measure, we can reproduce a random-effects meta-analysis with standardized mean differences outcomes and risk ratios for binary outcomes. Ninety-five percent (95\%) confidence intervals and twosided $p$-values for each outcome. For verify the heterogeneity between studies, on effect measures will be evaluated using both the $X 2$ test and the $I^{2}$ statistic. We will consider a value of $\mathrm{I}^{2}$ greater than $50 \%$ an indicative of heterogeneity satisfactory. Will be a sensitivity analyses based on the quality of the studies. Stratified meta-analyses will be used to explore estimates of heterogeneity according to: study quality, populations studied, logistics of intervention, and content of the intervention. Review Manager software (RevMan) will be used for all analyses, including meta-analysis, if possible. [24-27].

\section{Quality of evidence}

The Grading of Recommendations Assessment, Development and Evaluation (GRADE) will be used to verify the quality of evidence of the analyzed studies. The GRADE system assesses the limitations of the study, inconsistencies, indirect evidence, inaccuracies, and publication biases, classifying the level of evidence of the reviewed studies as high, moderate, low, or very low.

\section{Discussion}

First-line conservative interventions for OAB-wet or OAB-dry may generate benefits for individuals with this syndrome. The BT may show and have been showing positive results due to its low complexity requiring simple technology, also because it involves behavioral changes in relation to voiding behavior and health habits, and finally due to its low cost for its effectiveness in prescription and treatment [5,16-20]. 
medRxiv preprint doi: https://doi.org/10.1101/2022.03.01.22271687; this version posted March 2, 2022. The copyright holder for this preprint (which was not certified by peer review) is the author/funder, who has granted medRxiv a license to display the preprint in perpetuity.

It is made available under a CC-BY 4.0 International license.

This study design was chosen because in this way, we can evaluate and update the highest level of available evidence. However, more conclusive and updated

219 findings can be obtained that support clinical practice, in addition to promoting other studies of superior quality on this subject [23].

In this way, we can obtain solid and conclusive evidence, whether or not there is evidence to support clinical practice, in addition to promoting high-quality studies on the subject.

\section{Author Contributions}

Conceptualization: Anna Karoline Lopes Rocha, Silvia Elizate Monteiro, Maria Volpato. Dinah Verleun, Lilian Valim, Cássio Riccetto, Simone Botelho.

Data curation: Anna Karoline Lopes Rocha, Maria Volpato, Cássio Riccetto, Simone Botelho.

Formal analysis: Anna Karoline Lopes Rocha, Maria Volpato, Cássio Riccetto, Simone Botelho.

Funding acquisition: Anna Karoline Lopes Rocha, Silvia Elizate Monteiro, Maria Volpato, Cássio Riccetto, Simone Botelho.

Investigation: Anna Karoline Lopes Rocha, Dinah Verleun, Lilian Valim.

Methodology: Anna Karoline Lopes Rocha, Silvia Elizate Monteiro, Dinah Verleun, Lilian Valim, Cássio Riccetto, Simone Botelho.

Project administration: Cássio Riccetto, Simone Botelho.

Resources: Anna Karoline Lopes Rocha, Dinah Verleun, Lilian Valim.

Software: Anna Karoline Lopes Rocha, Dinah Verleun, Maria Volpato

Supervision: Silvia Elizate Monteiro, Cássio Riccetto, Simone Botelho. 
241 Validation: Silvia Elizate Monteiro, Lilian Valim

242 Writing - original draft: Anna Karoline Lopes Rocha, Silvia Elizate Monteiro, 243 Maria Volpato. Dinah Verleun, Lilian Valim, Cássio Riccetto, Simone Botelho.

244 Writing - review \& editing: Anna Karoline Lopes Rocha, Silvia Elizate Botelho. 


\section{Acknowledgements}

248 We thank you the groups of the all universities - UNIFAL-MG, UNICAMP-SP and PUCMG as well as the Coordenação de Aperfeiçoamento de Pessoal de Nível Superior Brazil (CAPES), Fundação de Amparo à Pesquisa do Estado de Minas Gerais (FAPEMIG) and Research Incentive Fund, PUC MINAS, MG, Brazil.

\section{Supporting Information}

S1 Table: Table 1. Characteristics of the Studies. OAB: Overactive Bladder

S2 Table: Table 2. Exclusion criteria from systematic review and meta-analysis analysis of randomized controlled trials to evaluated the effects of BT in individuals with OAB-wet or OAB-dry.

S1 File: PRISMA-P (Preferred Reporting Items for Systematic review and MetaAnalysis Protocols) 2015 checklist: Recommended items to address in a systematic review protocol*.

S2 File: PROSPERO International Prospective Register of Systematic Reviews.

\section{References}

1. Abrams P, Cardozo L, Fall M, Griffiths D, Rosier P. The standardization of terminology of lower urinary tract function report from the standardization subcommittee of the International Continence Society. Neurourol Urodyn. 2002;21(2):167-178.

270 2. Haylen BT, de Ridder D, Freeman RM, Swift SE, Berghmans B, Lee J, et al.

271 An International Urogynecological Association (IUGA)/International Continence 272 Society (ICS) joint report on the terminology for female pelvic floor dysfunction. Int 273 Urogynecol J. 2010;21(1):5-26. https://doi.org/10.1007/s00192-009-0976-9.

274 3. Abrams P, Cardozo L, Wagg A, Wein A. 6th International Consultation on 275 Incontinence, Tokyo, September 2016. 6th ed. Tokyo, Publisher: Bristol, UK: 
medRxiv preprint doi: https://doi.org/10.1101/2022.03.01.22271687; this version posted March 2, 2022. The copyright holder for this preprint (which was not certified by peer review) is the author/funder, who has granted medRxiv a license to display the preprint in perpetuity.

International Continence Society (ICS) and International Consultation on Urological

277 Diseases (ICUD); 2016.

278 4. D'Ancona C, Haylen B, Oelke M, Abranches-Monteiro L, Arnold E, Goldman H, 279 et al. Committee ICS and the ICS Working Group on Terminology for Male Lower 280 Urinary Tract \& Pelvic Floor Symptoms and Dysfunction. The International Continence 281 Society (ICS) report on the terminology for adult male lower urinary tract and pelvic 282 floor symptoms and dysfunction. Neurourol Urodyn. 2019;38(2):433-77.

283 5. Bo K, Frawley HC, Haylen BT, Abramov Y, Almeida FG, Berghmans B, et al. 284 An International Urogynecological Association (IUGA)/ International Continence 285 Society (ICS) joint report on the terminology for the conservative and 286 nonpharmacological management of female pelvic floor dysfunction. Neurourol Urodyn. 2017; 36 (2): 221-244.

288 6. ICS Standards 2022: The 2022 compilation of the International Continence 289 Society Standardisations, Consensus statements, Educational modules, Terminology 290 and Fundamentals documents, with the International Consultation on Incontinence algorithms

(2022). Retrieved

09 February 2022, from https://www.ics.org/members/shop/icsstandards2022

293 7. Abrams P, Kelleher CJ, Kerr LA, Rogers RG. Overactive bladder significantly affects quality of life. Am J Manag Care. 2000; 6:S580.

295 8. Irwin DE, Milsom IM, Kopp Z, Abrams P, Cardozo L. Impact of overactive bladder symptoms on employment, social interactions and emotional well-being in six European countries.

BJU Int. 2006; 97(1):96-100.

DOI:10.1111/j.1464410X.2005.05889.x

299 9. Zhu L, Cheng X, Sun J, Lv S, Mei S, Chen X, et al. Association between 300 menopausal symptoms and overactive bladder: A Cross-Sectional Questionnaire 301 survey in China. PLoS One. 2015; 8;10(10):e0139599. doi: 302 10.1371/journal.pone.0139599.

303 10. Heidler S, Mert C, Temml C, Madersbacher S. The Natural History of the 304 Overactive Bladder Syndrome in Females: A Long-Term Analysis of a Health 305 Screening Project. Neurourology and Urodynamics 30:1437-1441 (2011). DOI 10.1002/nau.21093

307 11. Coyne KS, Sexton CC, Bell JA, Thompson CL, Dmochowski R, Bavendam T, et al. The prevalence of lower urinary tract symptoms (LUTS) and overactive bladder 
medRxiv preprint doi: https://doi.org/10.1101/2022.03.01.22271687; this version posted March 2, 2022. The copyright holder for this preprint (which was not certified by peer review) is the author/funder, who has granted medRxiv a license to display the preprint in perpetuity. It is made available under a CC-BY 4.0 International license .

309

310

(OAB) by racial/ethnic group and age: results from OAB-POLL. Neurourol Urodyn. 2013; 32:230-237. DOI: 10.1002/nau.22295

12. Milsom I, Altman D, Cartwright R, Lapitan MC, Nelson R, Sjöström S, et al. Epidemiology of urinary incontinence (UI) and other lower urinary tract symptoms (LUTS), pelvic organ prolapse (POP) and anal incontinence (AI). In: Abrams P, Cardozo L, Wagg A, Wein A, editors. Incontinence. 6th ed. Tokyo: International Continence Society; 2017.

13. Peyronnet B, Mironska E, Chapple C, Cardozo L, Oelke M, Dmochowski R, et al. A comprehensive review of overactive bladder pathophysiology: on the way to tailored treatment. Eur Urol. 2019 jun; 75(6):988-1000. DOI: 10.1016/j.eururo.2019.02.038

14. Ganz ML, Smalarz AM, Krupski TL, Anger JT, Hu JC, Wittrup-Jensen KU, et al. Economic costs of overactive bladder in the United States. Urology. 2010; 75:526532.e518. DOI:10.1016/j.urology.2009.06.096

15. ICS Standards 2020-2021: The 2020 - 2021 compilation of the International Continence Society Standardisations, Consensus statements, Educational modules, Terminology and Fundamentals documents, with the International Consultation on Incontinence algorithms (2021). Retrieved 08 February 2022, from https://www.ics.org/members/shop/icsstandards20202021

16. Berghmans B, Burgio K, Dumoulin C, Hagen S, Moore K, Nygaard I, et al. Committee 12. Adult Conservative Management. In: In: Abrams P, Cardozo L, Wagg A, Wein A, editors. Incontinence. 6th International Consultation on Incontinence (2016), International Continence Society, 6th ed. Paris: Health Publications Ltd. 2017; p. 14451631.

17. Gormley EA, Lightner DJ, Burgio KL, Chai TB, Clemens JQ, Culkin DJ, et al. DIAGNOSIS AND TREATMENT OF OVERACTIVE BLADDER (Non-Neurogenic) IN ADULTS: AUA/SUFU GUIDELINE. American Urological Association Education and Research. J Urol.2019 Sep;202(3):558-563.doi: 10.1097/JU.0000000000000309.

18. Burgio KL. Lifestyle and Behavioral Therapies for Urinary Incontinence [serial on-line] 2014 Ago-out. [Acesso in 20 de dec de 2021]; 1(1):[17 screens]. Disponível em:

URL http://www.glowm.com/section view/heading/Lifestyle\%20and\%20Behavioral\%20Th erapies $\% 20$ for $\% 20$ Urinary\%20Incontinence/item $/ 855$ 
medRxiv preprint doi: https://doi.org/10.1101/2022.03.01.22271687; this version posted March 2, 2022. The copyright holder for this preprint (which was not certified by peer review) is the author/funder, who has granted medRxiv a license to display the preprint in perpetuity.

It is made available under a CC-BY 4.0 International license .

19. Corcos J, Przydacz M, Campeau L, Witten J, Hickling D, Honeine C, et al. Guideline On Adult Overactive Bladder. Can Urol Assoc J. 2017; 11(5):E142-73. http://dx.doi.org/10.5489/cuaj.4586

20. Bø K, Berghmans LC. Nonpharmacologic Treatments for Overactive BladderPelvic Floor Exercises. Urology. 2000; 55 (5a).

21. Newman DK, Borello-France D, Sung VW. Structured behavioral treatment research protocol for women with mixed urinary incontinence and overactive bladder symptoms.Neurourol Urodyn. 2018 Jan;37(1):14-26. doi: 10.1002/nau.23244.

22. Mahony DT, Laferte RO, Blais DJ. BLAIS, D. Integral storage and voiding reflexes. Neurophysiologic concept of continence and micturition: DOI: 10.1016/00904295(77)90297-7

23. Wallace SA, Roe B, Williams K, Palmer M. Bladder training for urinary incontinence in adults. Cochrane Database Syst Rev. 2004; 2004(1):CD001308. DOI: 10.1002/14651858.CD001308.pub2

24. Moher D, Shamseer L, Clarke M, Ghersi D, Liberati A, Petticrew M, et al. Preferred reporting items for systematic review and meta-analysis protocols (PRISMAP) 2015 statement. Syst Rev. 2015 Dec;4(1):1 10.1186/2046-4053-4-1

25. Higgins JP, Savović J, Page MJ, Elbers RG, Sterne JA. Assessing risk of bias in a randomized trial. In: Cochrane Handbook for Systematic Reviews of Interventions. Wiley; 2019. p. 205-28.

26. Liberati A, Altman DG, Tetzlaff J, Mulrow C, Gøtzsche PC, loannidis JPA, et al. (2009) The PRISMA Statement for Reporting Systematic Reviews and Meta-Analyses of Studies That Evaluate Health Care Interventions: Explanation and Elaboration. PLoS Med 6(7): e1000100. https://doi.org/10.1371/journal.pmed.1000100

27. Review Manager (RevMan) [Computer program]. Version 5.4. The Cochrane Collaboration, 2020.

28. Guyatt GH, Oxman AD, Vist GE, Kunz R, Falck-Ytter Y, Alonso-Coello P, et al. GRADE: an emerging consensus on rating quality of evidence and strength of recommendations. $\quad$ BMJ. $2008 . \quad$ April;336(7650):924-6. 10.1136/bmj.39489.470347.AD 


\section{Abbreviations}

373 ICS - International Continence Society

374 BT - Bladder Training

375 OAB - Overactive Bladder

376 OAB-wet - Overactive bladder with urinary incontinence

377 OAB-dry - Overactive bladder without urinary incontinence

378 UUI - Urgency Urinary Incontinence

379 RCTs - Randomized Clinical Trials

380 PFMT - Pelvic Floor Muscle Training

381 PFM - Pelvic Floor Muscle 